\title{
Enhancing Self-Reliant of Students in Technical and Vocational Skills Through Work-based Learning for $4^{\text {th }}$ Industrial Revolution
}

\author{
Shirka Kassam Jwasshaka, Nor Fadila Mohd. Amin
}

\begin{abstract}
Enhancing skills through work-based learning enables graduates of higher institutions to be innovative, learn new skills, connect directly, and conveniently to world of work. Private sectors, partnership with higher institutions in making the education system better in this regard cannot be overemphasized. It is in view of this, that this study sought to critically review Nigeria higher institutions with regards to providing graduates with the needed TVET skills through work-based learning for self-reliant; owing to the challenges of the fourth industrial revolution. The study adopted systematic review where thirty-five (35) published journals articles were downloaded from web-based providers such as: Science direct, Scopus, Google scholar, Springer, and Willey online Library and so on. Twenty (20) articles were found to have met the demand of the study. The finding from the review revealed that work-based is lacking in the training of graduates in technical and vocational education training skills. Higher institutions based their training on classroom or school based making the graduates insufficient in skills. The reviewers recommended the inclusion of other aspects of training into the system to augment TVET skills such as exposing students to: industrial training, field trips, excursion, job shadowing, school-based enterprises, and school entrepreneurial ventures, internship/practicum, clinical work experiences, cooperative work experiences, youth apprenticeship and career days. Conclusion of the whole discussion is given at the end of the paper.
\end{abstract}

Index Terms: Technical, Vocational Education and Training (TVET), Work-based Learning, Skills.

\section{INTRODUCTION}

The unprecedented acceleration in technology occasioned by demands for skill and competency from graduates of higher institution calls for a proactive response to adjustment in our educational system. Literatures considered technical and vocational education and training as having the capacity to produce individuals with competent skills required by the labour market. The disposition of fresh graduates in technical skills competency in their places of endeavor have not proven this assertion because employers still perceived graduates as lacking the skills required. This may be obvious going by the increased unemployment rate of school leavers. Studies carried out on the reasons for increase in school leavers' unemployment status revealed that the graduates lacks relevant skills that can make them fit into the labor market [7],[4],[5],[3]. Education, especially in this era of fourth industrial revolution should lead to acquisition of

Revised Manuscript Received on October15, 2019.

Shirka Kassam Jwasshaka, Plateau State Polytechnic, Barkin Ladi, Nigeria.cassak4real@yahoo.ca

Nor Fadila Mohd. Amin, Department of Technical and Engineering Education, Faculty of Social Science and Humanities, Universiti Teknologi Malaysia, Malaysia. competent technical and vocational skills for self-reliant. The drivers of fourth industrial revolution have already shown that there will be mass job losses and new jobs that requires newer skills may perhaps emerged. The implication is that the skills that are not connected with the industrial revolution era may be rendered useless.

The meta-analysis of the published journals reviewed revealed that delivery of TVET skills over the years in Nigeria higher institution has little or no connection with modern industrial reality. The era of thousands graduates struggling for few slots of white collar jobs should be over if TVET is enhance through Work-based learning (WBL). Enhancing skills of students in TVET through WBL will be a powerful tool for national development, economic enlightenment and self-reliance and citizenship empowerment [2], [6], [13], [18].The power for economic develop of any nation and its citizens lies in the quality of knowledge and skill of its citizenry[5], [10], [11].

Policy provision of Technical and Vocational Education (TVE) as enshrined in Nigeria National Policy on Education NPE (2013) stipulates the following to:

1. Provide trained manpower in the applied sciences, technology and business particularly at craft, advanced craft and technical levels;

2. Provide the technical knowledge and vocational skills necessary for agricultural, commercial and economic development; and

3. Give training and impart the necessary skills to individual who shall be self-reliant economically.

As beautiful as the provision of the Nigerian National Policy on Education is, in favor of Technical and Vocational Education and Training (TVET), it is rather ridiculous to say that graduates roam the street in search of jobs. In Nigeria Unemployment, is on a steady rise between 2015 and 2018 in a percentage range of between 6.4 to 23.1 respectively according to records from National Bureau of Statistics, Nigeria (2018).

Re-engineering the delivery of skills in technical and vocational education in our institutions of learning through exposure of students in WBL could be a respite to over dependency in white collar jobs thereby reducing the increasing unemployment rate. Exposing graduates in TVET through WBL will improve their competency in skills and will enables them move to other jobs within the industry when gainfully employed [18]. 


\section{Enhancing Self-Reliant of Students in Technical and Vocational Skills Through Work-based Learning for $4^{\text {th }}$ Industrial Revolution}

\section{DEFINITION OF CONCEPTS}

TVET according to UNESCO (2012) is concerned with the acquisition of knowledge and skills for the world of work. This is to say that if TVET program are properly handled it can produce individual who does not depend on government job, but individuals who are capable to establish and be boss of the themselves. Elements in TVET according to UNESCO includes: Apprenticeship training, Vocational Education, Technical Education, Technical-Vocational Education (TVE), Occupational Education (OE), Vocational Education and Training (VET), Professional and Vocational Education (PVE), Career and Technical Education (CTE), Work-force Education (WE) etc. several of these terms are commonly used in specific area. Technical and Vocational Education and Training (TVET) is a programme designed to equip the youth with skills, knowledge and habit and cultures that would enable them to secure and hold job successfully [5], [12], [9], [14].

WBL can be defined as an institutional arrangement in which learners are concurrently exposed to both work and learning environments; is the experiential learning programmes that use the work environment as an important component of the curriculum[14], [16]. WBL demands that conscious and concerted effort are made to put in place strategies that would guarantee hand -on learning experiences [1], [14], [15]. Basically, a sure way of realizing these critical objectives is by the instrument of Work -based Learning (WBL) which emphasizes the establishment of a synergistic relationship between TVET institution, business and industry as well as community - based resources inventory [14], [20], [18], [17]. WBL affords learners ample opportunities to learn a variety of skills that guarantee synergistic relationship between the school and the world-of-work. It is an attempt to narrow the gap existing between theory and practice there by, making meaningful learning possible [3].

Synergizing TVET with WBL avails learners' opportunities to acquire a variety of skills upon exposure to rigorous academic activities side-by-side with hands-on career development experiences [14], [17].WBL forms a formidable link between classroom instruction, the world of work and career opportunities, as neither school-based learning nor involvement of a learner in professional work alone(i.e. apprenticeship) guarantees the occurrence of appropriate learning to the extent of satisfying the qualification requirements of the work-world [14], [16], [19]. Some of the WBL programmes relevant to TVET include industrial training, field trips, excursion, job shadowing, school-based enterprises and school entrepreneurial ventures, internship/practicum, clinical work experiences, cooperative work experiences, youth apprenticeship career fours guest and career days [14], [5]. This type of education is competency-based and aims at the acquisition of skills and sound scientific knowledge to be able to cope with the emergent demands of technology driven world for instance the fourth industrial revolution[15].

The fourth industrial revolution (4IR) is envisage to be a challenging time in the world of work because the way things are hitherto done will be changed, job automation will take the Centre stage with consequences of jobs losses. This rapid advancement in technological development has placed new demands on graduates needs for diverse competent skills to be able to sustain themselves in the new era [13], [18].The 4IR workforce will be unique and only individuals with adequate skills can serve in the available work opportunities [20]. Some of the indicator of 4IR includes: (i) a scientific and computer world; (ii) a technological or jet age demanding efficient use of computer in all spheres of life; (iii) an age requiring sound scientific and technological skills for individual to cope with its complexity; (iv) a world where emphasis will be more on accuracy, competence, efficiency and effectiveness which are derived from educational foundation; and (v) an era of highly skilled practitioners and generalists[17], [15], [19], [9].

\section{PROBLEM STATEMENT}

Learning TVET skills in Nigerian tertiary institutions is fast becoming deplorable, owing to the complaint among parents and industries that graduates of Nigeria higher institutions lack skills for self-employment[11]. With the current state of TVET system in Nigeria, it is obvious that government alone may not provide the students with the desired skills for efficient self-employment of its teaming graduates[16] [18]. This situation calls for paradigm shift from the traditional methods of teaching TVET skills to an approach in line with the need of the world of work through work-based learning. also, to enhance functional education and skill-oriented educational system [17].

To produce individuals who will stem the tide of the challenges of 4IR, school-workplace collaboration in TVET needs to be encouraged, to ensure qualitative and affordable education. that is hinged on skills and competencies acquisition for capacity building and sustainable development. The issue of making skills training and acquisition meaningful and relevant to the need of the society and employers of labour will remain a fantasy without effective school-workplace collaboration. The experiences students gain from the four months of Industrial Work Experience Scheme (SIWES)is not adequate to give them the necessary skills they need [3],[1],[20].

Much has been said and written on the need to train Nigerians graduates and youths to acquire employable skills in TVET for self-reliance in the absence of white-collar jobs; among the teeming population of graduates with the conventional types of education hitherto provided by our tertiary institutions [19].

The problem of this study is drawn from the meta-analysis table, where it was discovered that most journal reviewed concentrated on acquisition of skills through school-based TVET alone. Only a few studies indicated integration of TVET with WBL despite the inherent mutual benefits derivable from such fusion. Owing to the demographic increase of graduates of higher institution with a few or no white collar jobs, it is imperative to enhance TVET skills in students' through effective

Work-based learning for self-reliant. 


\section{RESEARCH QUESTIONS}

This study was interested in reviewing published journals on the influence of Work-based Learning in enhancing the delivery of Technical and Vocational Education and Training of students in skills acquisition for self-reliant. It sought to identify the scope of research work that has already been carried out and gap that exist in this area. To achieve this, the following research questions formulated:

1) What is the effectiveness of work-based Learning in augmenting TVET skills of students of Nigeria higher institutions?

2) What is the predominant methods through which students of Nigeria higher institution acquire self-reliant skills?

3) Is the School-based acquisition of TVET skills adequate for students' self-reliability in the era of fourth industrial revolution?

\section{METHODOLOGY}

\section{A. Methods of Data Collection and Analysis}

The study adopted critical review of published journal article searched and downloaded from online data-based using relevant key words to provide access to the journals such as: effectiveness of work-based learning in TVET, self-reliant in TVET through WBL, TVET skills for fourth industrial revolution through WBL, and so on. the database from which sources were downloaded includes Educational Resources Information Centre (ERIC) such as; Google scholar, Science direct, Willey online Library, Springer and so on. Conference papers were also found relevant for use in the study. Total of thirty-five (35) journal articles published between 2010 and 2018 were used. After critical review, 21 of the journals were found to have met the desire of the reviewers for the study. the rejected journals did not meet the requirements for the study at hand. Numbers were assigned against each authors name which are used in citation in the body text as shown in the meta-analysis in Table 1.

Based on Table1, it shows the previous studies carried out on TVET in relation to work-based learning, different approaches were adopted by authors. Each one also has its target group involves in their studies. From the results of the journal reviewed it was discovered that not much studies were found on enhancing TVET through WBL as most authors concentrated on the conventional school-based TVET skills.

\section{RESULTS AND DISCUSSIONS}

Higher educational institutions are responsible to offering courses that are capable of shaping the future life of its teaming young population that will add value to the society. The quality of a nation's workforce depends on the quality of its educational system. The aspect of Nigeria National Policy of Education on higher education particularly technical education is meant to train individual in skill for self-sustainability. In spite of this mandate, graduates of higher institutions still do not have sufficient skills to perform on the jobs [20].Emphasis on restricting skills acquisition through class-based as against work-based might have been a contributing factor. Hands-on skills training produces individuals who are competent in their fields of endeavors than class-based training. According to [12] work-based TVET is capable of providing individual with functional education and skill-oriented for a successful educational life; TVET is competency-based that can provide skills and sound scientific knowledge to cope with the emergent demands of technology driven world for instance the fourth industrial revolution [15].

Collaboration of private sector with the institutions provide the graduates opportunities to be exposed to real life situation as government alone may not adequately provide the needed skills [16], [18]. Additionally, it affords the graduates opportunities to also learn from experienced field workers. As technology advances, skill demand for labour market also is being refined in some cases change. Only highly skilled personnel can function during the 4IR according to [12], [11]. To achieve this, there is need for paradigm shift in the traditional approach to TVET skills acquisition to prioritizing WBL with TVET such as industrial training, field trips, excursion, job shadowing, school-based enterprises, and school entrepreneurial ventures, internship/practicum, clinical work experiences, cooperative work experiences, youth apprenticeship, career fours guest, and career days [14], [5]. [1], [2], [3] asserts that when conscious and concerted efforts are made to put in place strategies that would guarantee hand-on learning in TVET through WBL experiences, the graduates will be better inform of the challenges of 4IR.

Synergizing TVET with WBL may be a powerful tool for national development, economic enlightenment and self-reliance and citizenship empowerment according to [2] [6], [13], [18]. Previous studies revealed that fourth industrial revolution has mixed feelings in the minds of the graduates, for instance; mass job losses and newer jobs that may require highly skill graduates to perform. The solution to nib the challenges in the bud is to shift from predominantly skills acquisition through school-based training to blending it with work-based training.

\section{FURTHER SUGGESTIONS}

From the findings, it is pertinent to suggests that for Nigeria higher institution to produce graduates with technical skills to be self-reliant in this era of 4IR, the training approach need to shift from the conventional school-based to emphasis on areas such as industrial training, field trips, excursion, job shadowing, school-based, enterprises and school entrepreneurial ventures, internship/practicum, clinical work experiences, cooperative work experiences, youth apprenticeship and career days. Exposing students to these activities may produce high-quality skills relevant to real work situations than learning that the entire activities begins and ends in the classrooms; it will also provide skills that are more up-to-date in line with the current labour market. 
Enhancing Self-Reliant of Students in Technical and Vocational Skills Through Work-based Learning for $4^{\text {th }}$ Industrial Revolution

Table 1.1Meta-analysis of Journal Papers

\begin{tabular}{|c|c|c|c|c|c|c|c|}
\hline \multirow[t]{2}{*}{ Authors } & \multirow[t]{2}{*}{ Design } & \multicolumn{3}{|c|}{ Levels of Study } & \multicolumn{3}{|c|}{ Approaches } \\
\hline & & $\begin{array}{l}\text { You } \\
\text { ths }\end{array}$ & Sec & $\begin{array}{l}\text { Terti } \\
\text { ary }\end{array}$ & $\begin{array}{l}\text { TVET } \\
\text { Skill }\end{array}$ & $\begin{array}{l}\text { TVET } \\
\text { /WBL }\end{array}$ & $\begin{array}{l}\text { Target } \\
\text { group }\end{array}$ \\
\hline Ernest, U., O. et al (2016) [1] & Survey & & & $\sqrt{3}$ & & $\sqrt{ }$ & Lecture \\
\hline Paterson, Keevy\&Boka, (2017) [2] & Survey & & & & $\sqrt{ }$ & & Student \\
\hline Ojonugwa, I., O. et al (2015) [3] & Survey & & & $\sqrt{ }$ & $\sqrt{ }$ & & Student \\
\hline Janikova, M. (2017) [4] & Survey & & & & $\sqrt{ }$ & & Dropout \\
\hline Chijioke, P., \&Tambari, M. (2017) [5] & $\begin{array}{l}\text { Desk } \\
\text { Review }\end{array}$ & $\sqrt{ }$ & & & $\sqrt{ }$ & & Dropout \\
\hline Inyiagu, E., E. (2014) [6] & Survey & $\sqrt{ }$ & & & $\sqrt{ }$ & & Industry \\
\hline Mohamad, S., R. (2010) [7] & Survey & & & & $\sqrt{ }$ & & $\begin{array}{l}\text { TVET } \\
\text { teacher }\end{array}$ \\
\hline $\begin{array}{l}\text { Obuanya, T., C. \&Oluwasola, J., A. (2015) } \\
\text { [8] }\end{array}$ & Survey & & & & $\sqrt{ } \sqrt{ }$ & & $\begin{array}{l}\text { Policy } \\
\text { issues }\end{array}$ \\
\hline Okoye, E., R., K. \&Okwele, P., C. (2017) & Critical & & & & $\sqrt{ }$ & & Policy \\
\hline [9] & Review & & & & & & issues \\
\hline $\begin{array}{l}\text { Jonathan, N., \& Monday, E., M. (2016) } \\
\text { [10] }\end{array}$ & $\begin{array}{l}\text { Desk } \\
\text { Review }\end{array}$ & & & & $\sqrt{ }$ & & Opinion \\
\hline Okoye, R., \&Arimonu, O., M. (2016) [11] & $\begin{array}{l}\text { Desk } \\
\text { Review }\end{array}$ & & & & $\sqrt{ }$ & & Policy \\
\hline Nwankwo, C., F., et al (2013) [12] & $\begin{array}{l}\text { Desk } \\
\text { Review }\end{array}$ & & & & $\sqrt{ }$ & & $\begin{array}{l}\text { TVET } \\
\text { Teachers }\end{array}$ \\
\hline Anaele, E., O. et al (2014)[13] & Survey & & & & & & Teachers \\
\hline Ugochukwu, P., N., A. (2013) [14] & Survey & & & & & $\sqrt{ }$ & Graduates \\
\hline Maigida, J., F., et al (2013 [15] & $\begin{array}{l}\text { Desk } \\
\text { Review }\end{array}$ & & & $\sqrt{ }$ & & & Policy \\
\hline Oviawe, I., J. et al (2017a) [16] & $\begin{array}{l}\text { Desk } \\
\text { Review }\end{array}$ & & & & & $\sqrt{ }$ & Policy \\
\hline Alayande, E., \&Akanbi, O., G. (2017) [17] & Historical & & & & & $\sqrt{ }$ & Teachers \\
\hline Oviawe, I., J., et al (2017b) [18] & Survey & & & & & $\sqrt{ }$ & Teachers \\
\hline Odo, I., M. (2012) [19] & Survey & & & & $\sqrt{ }$ & & Method \\
\hline Bhurtel, A., (2015) [20] & $\begin{array}{l}\text { Desk } \\
\text { Review }\end{array}$ & & & & $\sqrt{ }$ & & Opinion \\
\hline Adebisi, T., A. (2014) [21] & $\begin{array}{l}\text { Desk } \\
\text { Review }\end{array}$ & & & & $\sqrt{ }$ & & Opinion \\
\hline
\end{tabular}

\section{CONCLUSION}

From the findings of the study we understand that school-based approach dominate the way Polytechnic graduates acquire skills. The work-based approach which exposed the graduates to industrial practices for the period of four months for the whole period of their study may not be enough to augments what is learned in school. In this era of 4IR, students need to have opportunity to constantly learn new skills and newer ways of doing things to be more productive and profitable. With the forewarned attendant consequences of the fourth industrial revolution characterized by mass job losses and emergence of high-level skills, graduates need to be constantly more innovative, creative and interactive with experienced workers in the real-life work environment. Higher education in Nigeria which have the policy mandate to produce graduates who will be self-reliant, need to renew approaches in TVET skill delivery by blending it with work-based learning as the current approaches is observed to be inefficient.

\section{ACKNOWLEDGMENT}

First and foremost, my gratitude goes to the Management and the School of Graduate Studies, University of Technology, Malaysia for providing enabling environment for learning. I thank all the authors whose journals are made available for used by researchers to enhance knowledge. I owe my amiable supervisor, Dr. Nor Fadila Amin Mohd a huge debt of appreciation for her patience, open-mindedness, relentless efforts, and for her contributions in adding value to this article. I say thank you. And to all the lectures in the department of technical and engineering education of this university for their knowledgeable contributions.

\section{REFERENCES}

1. Amadi, N., P., U., (2013). Appraising Work-Based Learning Experiences of Technical and Vocational (Teacher) Education and Training (TVET) Programmes in Nigeria. Mediterranean Journal of Social Sciences 4(5), 137-146.

2. Alayande, E., \&Akanbi, O., G. (2017). Prospects of Technical, Vocational Education and Training (TVET) in Nigeria: Bridging the Gap Between Policy Document and Implementation. The International Education Journal; Comparative

Perspective 1692), 1- 5. 
3. Anaele, E., O., Adelakun, O., A., Olumoko, B., O., \&Kanu, J., A. (2014 Aug.). Strategies for Empowering Individuals for Self-Employment Through Technical, Vocational Education and Training(TVET) in Nigeria. International Journal of Education Learning and Development 2(3),19.

4. Bhurtel, A., (2015). Technical, Vocational Education and Training in Workforce Development: Journal of Training and Development 1(1), 77-84.

5. Chijioke, P., \&Tambari, M. (2017 Mar.). Technical, Vocational Education and Training as a Tool for Sustainable Empowerment of Youths in Niger Delta Nigeria: International Journal of Social \& Science Educational Research 5(1),29-38.

6. Ernest, U., O.;Ezeji, H., A.; Edeth, N., I. \&Etonyeaku, E., A., C. (2016 Aug.). Effective Implementation of TVET-Industry Partnership for Employability of Graduates Through Work-Integrated Learning in Nigeria Universities; Review of European Studies 8(3), 307- 315.

7. Federal Republic of Nigeria, (2013). National Policy on Education; $6^{\text {th }}$ Ed.Lagos Nigeria NERDC Press

8. Federal Government of Nigerian FGN (2017).National Bureau of Statistics Nigeria. Retrievedfromhttps://tradingeconomics.com/nigeria/unemployement-ra te Retrieve 5/2/2018.

9. Inyiangu, E., E. (2014). Challenges Facing Technical and Vocational Education in Nigeria: Journal of Education Policy 1(1),40-45.

10. Jonathan, N. \& Monday, M., E. (2017). Technical, Vocational Education and Training as a Tool for National Sustainable Development in Nigeria: The International Journal of Social Sciences and Humanities Invention 4(9) 3983-3988.

11. Maigida, J., F., Saba, T., M. \& Namkere, J., U. (2013 Mar.) Entrepreneurial Skills in Technical Vocational Education and Training as a Strategic Approach for Achieving Youth Empowerment in Nigeria: International Journal of Humanities and Social Sciences 3(4) 3030-309.

12. Mohamad, S., R., Mohd, Y.; Napsiah, I.; Mohammad, R., \& Abd Rauf, A., R. (2010 Jun.). Development of Employability Skills Assessment Tool for Manufacturing Industry: Journal of Mekanika 30, 48-61.

13. Nwankwo, F., C. \& Obeta, I., C. (2013). Integrating Technical and Vocational Education in Youths Empowerment Programmes: An Approach to Nation Building and Job Creation in Nigeria. Journal of Education and Practice 4(16), 87-90.

14. Odo, I., M.;Adenle, S., O. \& Okwori, R., O. (2012). Enhancing Mastery of Practical Skills in Students of Vocational and Technical Education Through Activity Based Instructions. Journal of Technical Education and Training (JTET) 4(2),21-29.

15. Ogbuanya, T., C. \& Oluwasola, J., A., (2015 Feb.). Quality Technical, Vocational Education and Training: A Tool for Self-Reliant. IOSR Journal of Computer Engineering 17(1),30- 35.

16. Ojonugwa, I., O.; Hamzah, R.; Bakar, R., A., \& Rashid, M., A. (2015 Jul.). Evaluation Self- Efficacy Expected of Polytechnic Engineering Students as a Measure of Employability: International Journal of Education\& Literacy Studies 3(3), 24-30.

17. Okoye, E., R. (2013May). Private-Public Partnership and Technical Vocational Education and Training (TVET) in a Developed Economy. Arabian Journal of Business and Management 2(10),51-61.

18. Okoye, K., R. \& Okwelle, P., C. (2017). New Perspective on Technical and Vocational and Training in NigeriaBritish Journal of Education, Society \& Behavioral Science, 23(4), 1- 9.

19. Okoye, R., \&Arimonu, O., M. (2016). Technical and Vocational Education in Nigeria: Issues, Challenges and a way Forward. Journal of Education and Practice 7(3), 113-118.

20. Oviawe, I., J.;Uwameiye, R., \& Uddin, P., S., O. (2017April). Bridging Skills Gap to meet Technical, Vocational Educational and Training School-Workplace Collaboration in the $21^{\text {st }}$ Century. International Journal of Vocational Education and Training Research 3(1), 7-14.

21. Oviawe, I., J., Uwameiye, R., \& Uddin, P., S., O. (2017Aug.). Best Practices in Technical Education Programme for Students' capacity Building and Sustainable Development in the $21^{\text {st }}$ Century. Journal of Technical Education and Training (JTET) 9(2), 57-68.

22. Parterson, A., K. \&Boka, K. (2017). Exploring a Work-Based Values Approach in South African TVET Colleges to Improve Employability of Youth: Literature Review. Johannesburg; JET Education Services, $1-19$.

23. UNESCO-UNEVOC, (2012). International Centre for Technical and Vocational Education and Training; World TVET Database Nigeria.

\section{AUTHOR PROFILE}

First Author: Shirka Kassam Jwasshaka, Plateau State Polytechnic,

Barkin Ladi, Nigeria. cassak4real@yahoo.ca
Second Author: Nor Fadila Mohd. Amin, Department of Technical and Engineering Education,, Faculty of Social Science and Humanities, Universiti Teknologi Malaysia, Malaysia. 